\title{
On the Development and Improvement of Socialist Consultative Democracy in the New Era
}

\author{
Yanli Wan", Qiyan Yan" \\ School of Public Administration, Southwest University for Nationalities, Chengdu, China \\ ${ }^{\#}$ These authors are co-first authors of the article
}

\begin{abstract}
To promote socialist modernization and socialist democracy with Chinese characteristics, we need to uphold deliberative democracy with Chinese characteristics. To give full play to the important role of socialist consultative democracy is a realistic requirement for achieving the great success of socialism with Chinese characteristics in the new era. In the new era, socialist consultative democracy needs to constantly innovate consultative forms and promote China's consultative democracy to become mature and perfect.
\end{abstract}

Keywords: New era, Socialism, Deliberative democracy.

\section{Introduction}

Under the leadership of the Communist Party of China, socialist consultative democracy allows more people to participate in consultation before and during decision-making to improve the quality and level of decision-making in response to various problems existing in reform and development[1]. Understanding the development of socialist consultative democracy will help us further improve it in the new era.

\section{The Development of Socialist Consultative Democracy}

Consultative democracy in China originated from the theory and practice of the Anti-Japanese National United front of the Communist Party of China, and gradually formed and developed in the practice of China's revolution, construction and reform and opening up.

In March 1940, During the War of Resistance against Japanese Aggression, Mao Zedong proposed the "three-thirds system" of political power in the article "The Problem of Political Power in the Anti-Japanese Base Areas". The establishment of the "three-three system" democratic regime in Shaanxi-Gansu-Ningxia border area is to unite all forces that can be united, win the hearts of the people, and mobilize the enthusiasm of all classes of resistance against Japan. At the same time, different sectors are encouraged to express their views, and the interests of all parties are taken into account and safeguarded. Therefore, the "three-three system" regime became a form of political consultation, which not only promoted the victory of the Anti-Japanese War, but also promoted the germination and establishment of consultative democracy in the early days of the founding of the People's Republic of China.

The party's first generation of central collective leadership with Mao Zedong at its core put forward a series of original and important thoughts on deliberative democracy, proposed the establishment of a people's democratic united front regime, and determined that deliberative democracy was the basic design of new China's political system.

From September 21 to 30, 1949, the first Plenary session of the Chinese People's Political Consultative Conference (CPPCC), composed of representatives of the Communist Party of China, democratic parties, democratic personages without party affiliation, people's organizations, regions, the People's Liberation Army, ethnic minorities, religious circles, overseas Chinese and other patriotic and democratic personages, was solemnly held in Beijing. In addition to announcing the founding of the People's Republic of China to the Chinese people, the meeting also marked the beginning of the nationwide implementation of consultative democracy, a new form of democracy. The convening of the new CPPCC opened historical chapters in the development of China's democratic politics.

After the reform and opening up, China entered a new period. The central leadership group represented by Deng Xiaoping, Jiang Zemin and Hu Jintao attached great importance to and developed the theory and practice of deliberative democracy, and many forms of deliberative democracy began to gradually recover, thus restoring the vitality of deliberative democracy in the new era.

With the diversified development of consultative democracy, China has made a clear position on consultative democracy. The opinions of the CPC Central Committee on Strengthening the work of the CPPCC in 2006 clearly pointed out that: "Two important forms of socialist democracy in China are the exercise of the people's rights through elections and voting, and full consultation among all sectors of the people before major decisions are made to reach consensus on common issues as far as possible. "This is the first time that the idea of "consultative democracy" has been formally put forward in China.

In 2012, the term "socialist consultative democracy" was first proposed in the report to the 18th National Congress of the CPC. Since then, socialist consultative democracy has gradually developed and grown in China. The Communist Party of China useful exploration and practice of deliberative democracy has made all-round development and improvement of socialist deliberative democracy in China.

In 2017, the report to the 19th National Congress of the CPC once again pointed out that "consultative democracy is an important means of realizing the Leadership of the CPC, and a 
unique form and unique strength of China's socialist democracy."

Deliberative democracy with Chinese characteristics is a direct manifestation of people-centered democracy and an important way for the people to participate widely in political life. It has a unique position in China's democratic politics. As General Secretary Xi Jinping has said: "Deliberative democracy is unique in China's socialist democratic politics, unique, unique form of democracy, it is derived from the Chinese nation formed over a long period of time the world public, eclecticism, seeking common ground while putting aside differences, such as excellent political culture, from the reality of modern China's political development after process, from the communist party of China leads the people in the long-term practice of revolution, construction and reform, It is derived from the great creation in the political system made by all political parties, organizations, ethnic groups, social strata and people from all walks of life since the founding of the People's Republic of China, and from the continuous innovation in China's political system since reform and opening up. It has a profound cultural, theoretical, practical and institutional foundation[2]." This important judgment not only outlines the emergence and development of deliberative democracy in China, but also demonstrates its unique position and profound foundation. It is a theoretical guide for us to understand and adhere to deliberative democracy with Chinese characteristics.

\section{Problems are being Raised in the Practice of Socialist Consultative Democracy}

It is the strong historical mission and responsibility of the CPC to make greater contributions to the political civilization of mankind. In his report to the 19th CPC National Congress, $\mathrm{Xi}$ Jinping stressed, "We are fully confident and capable of bringing into full play the strengths and characteristics of China's socialist democracy and making a contribution full of Chinese wisdom to the political progress of mankind. "Socialist consultative democracy is a democratic system with unique advantages[3]. It is the Chinese wisdom and plan that the Chinese nation has contributed to mankind's quest to build a better social system.

Of course, China's socialist consultative democracy is not perfect. In the process of developing and practicing consultative democracy, there are still some problems, such as insufficient understanding of consultative democracy by some leading officials and citizens, imperfect institutions and mechanisms of consultative democracy, and the implementation of consultation results to be strengthened.

\subsection{There are Deficiencies in Ideological Understanding}

Consultative democracy emphasizes both the process of consultation and the universality of the participants in the process of consultation. Therefore, consultative democracy should be a multi-party consultation and democracy. However, in the real consultation process, the leading cadres at all levels do not pay attention to the consultation opinions of some groups because of the great differences in the consultation ability, social work and knowledge level of the consultation subjects. At the same time, leading cadres of all departments and levels do not have a thorough understanding of the theory of deliberative democracy, and their enthusiasm, initiative and creativity are poor. Citizens' awareness of orderly participation in consultative democracy is weak, and the number of participants is relatively low.

In the specific implementation, some of the departments, the leading cadre "problem to negotiate", "want to negotiating negotiation, don't want to negotiate consultation" phenomenon occurs frequently, the negotiation as a "task" to complete, deliberative democracy emphasizes "equality", "negotiated consensus" and "legal decisions" values failed to get real, Consultation is characterized by arbitrariness, coping and formalism. In some cases, resolutions have been basically formed before consultations, and opinions and suggestions put forward during consultations have not been adopted or accepted. Consultative democracy has become a mere formality, and its role has not been fully played.

\subsection{The Institutions and Mechanisms of Consultative Democracy are not Perfect}

At present, there is a widespread phenomenon that consultation for consultation and coordination is more important than consultation. In the practice of grassroots democracy, there are usually more "speech making and discussion" consultations than "debate and deliberation" consultations. In most cases, "a few people take the lead to speak and the majority of people raise their hands to agree". Whether the consultation results really reflect public opinion may not be taken seriously. It is difficult to achieve full consultation and full democracy in the mode of "consultation in case of some matter and meeting in case of no matter". In particular, there is also a lack of operational standards on how much consultation is considered as relatively democratic[4]. The consultative body, content, time and form of consultative democracy, as well as how to apply the results of consultative democracy to decision-making, need to be further regulated and restrained. At the same time, consultative democracy still lacks a certain supervision and accountability mechanism, leading to weak transparency, openness and democracy in some places, and the phenomenon of negotiation results being falsified, indifferent and ignored.

\subsection{The Implementation of the Outcomes of the Consultations Needs to be Strengthened}

In the implementation of consultative democracy, there is a lack of implementation and supervision of the implementation of consultation results, which makes it difficult to turn the consultation opinions and suggestions into reality and implement them, and the purpose and effect of consultation are greatly compromised. The process was lively in form, but the evaluation and feedback on the implementation of the results were not transparent. In the process of consultation, although consensus and conclusions have been reached on some issues through consultation, it is difficult to implement them in practice. There is a phenomenon of "emphasizing the process rather than the results", which makes the consultation results "empty"[5]. Although the political consultation system has been written into the Constitution and has a reasonable and legitimate status, the results of consultation are not effectively guaranteed by law and often remain in writing. 
This consultative democracy, which lacks institutional constraints and legal supervision, is difficult to implement.

\section{Improvement of Socialist Consultative Democracy}

\subsection{Strengthen Participation Consciousness and Cultivate Consultation Subjects}

One is good at using various publicity media, improve the awareness of participation of the masses. Give full play to the newspapers, books, mobile phones, Internet and other emerging media, intensify propaganda, innovation propaganda media and forms by filming a short video, film, literature and art joint performance into the villages, prize popular forms of entertainment such as correct, guide the active participation of the grassroots democratic consultation activities, reasonable expression of self-interest appeal adequately, Conscientiously exercising democratic rights in their hands. Second, we need to strengthen the awareness of consultative democracy among leading officials. Departments and leading cadres at all levels should be good at using the style of leadership of democratic consultation, seriously listen to the opinions of the grass-roots feedback up advice, full knowledge to improve the level of ruling ability, leadership, cultivate the spirit of consultation is the important guarantee of the deliberative democracy socialist political development of our country, so as to improve the consciousness of deliberative democracy. Third, we need to foster consultative bodies. Fully develop all kinds of social organizations and groups, and expand the opportunity and to express the carrier of social each stratum, and to enlarge the range of consultative body to participate in breadth and depth, fully respect the interests of the expression of different social classes, the minority group or weak force into the decision to participate in public affairs, so as to better play to the advantages of deliberative democracy.

\subsection{Strengthen System Construction and Innovate Negotiation Forms}

First, from the central to local governments, we should gradually establish a system of consultative democracy that is connected, orderly and efficient, promote its institutionalized, standardized and procedural operation, and bring it to the road of legalization. Second, we will strengthen legislation on political consultation, improve and improve the legal system for deliberative democracy, put deliberative democracy on the track of law, and ensure that deliberative democracy has laws to go by and rules to follow. Third, establish a sound coordination and feedback mechanism, scientifically set time limits and requirements for the handling of consultation opinions by party committees and governments, as well as time limits and requirements for the handling of feedback by government functional departments, in the form of systems, and form norms for compliance and implementation[6]. Fourth, we should have the courage to carry out reform and innovation, learn from the consultation experience of advanced regions in China, draw on the valuable achievements of western countries in consultation in a reasonable way, develop appropriate forms of consultation in light of actual conditions, promptly summarize experience and practices, constantly innovate forms of consultation, and encourage more people to participate in the consultation process.

\subsection{Attach Importance to Consultation and Promote the Effective Implementation of Consultation Results}

First, we have established a supervision mechanism for the implementation of consultative democracy, aroused the enthusiasm of the general public, made the operation of consultative democracy more open and transparent, innovated oversight methods, and made active use of the Internet, mobile phones and other modern scientific and technological means to strengthen oversight of the operation of consultative democracy. Second, improve the accountability mechanism for the implementation of consultative democracy, make accountability institutionalized, procedural and standardized, and make the implementation of consultative democracy an important basis for assessing leading officials. Third, establish a system for the implementation, tracking and supervision of consultation results to ensure that the results are truly and effectively implemented and overcome the phenomenon of "empty" consultation results. At the same time, supervision should also be exercised over the implementation of the results of the consultation, and further consultations should be conducted on how to solve and correct problems and deviations arising from the implementation of the results of the consultation.

\section{Conclusion}

Socialist consultative democracy has grown and matured in the course of the Chinese nation's exploration for independence. It is a form of democracy based on China's own soil and belongs to both China and the world. Deliberative democracy with Chinese characteristics is a form of democracy "deeply rooted in the creative practices of the people." It strives to "apply the insights and insights of all parties to the governance of the country." It has "enriched the forms, expanded the channels and deepened the connotation of democracy."

With China's economic and social development and the continuous improvement of people's living standards, the people's awareness of democracy and demand for participation in political life are growing. We need to adapt to the new requirements for expanding people's democracy, continue to actively yet prudently advance political restructuring, promote extensive, multi-tiered and institutionalized development of consultative democracy, further leverage the unique advantages of socialist consultative democracy, and ensure that the position of the people as masters of the country is implemented in the country's political and social life. Standing at a new historical starting point, the Party and the state will keep to the theme of The Times, deepen their understanding of socialist consultative democracy in practice, and innovate the forms and channels of consultative democracy. While promoting the healthy development of Socialist consultative democracy in China, they will contribute more Chinese wisdom to the development of democracy in the world. 


\section{References}

[1] Chang Qingtao. On the Development and Perfection of socialist Consultative Democracy [J]. Legality Vision, 2020(21): 204-205.

[2] Xi Jinping. Win a Decisive Victory in Building a Moderately Prosperous Society in all Respects and Win the Great Victory of Socialism with Chinese Characteristics in the New Era-Report at the 19th National Congress of the Communist Party of China [R]. Beijing: People's Publishing House, 2017.

[3] [3] Lin Shangli. Consultative Politics: A Reflection on the Development of Democratic politics in China [J]. Academic Monthly, 2003(04): 19-25.

[4] Guo Wanmin. Practice, problems and Countermeasures of Chinese Deliberative Democracy $[\mathrm{J}]$. Frontier, 2010(19): 18-21.

[5] Li Zhichang. On the construction of socialist deliberative democracy $[\mathrm{J}]$. Journal of the Party School of the CPC Yunnan Provincial Committee, 2014, 16(04): 23-26.

[6] Meng Lan. On the problems and solutions of grass-roots deliberative democracy [J]. Journal of Jilin Institute of Socialism, 2015(02): 18-20. 